\title{
IAMJ
}

INTERNATIONAL AYURVEDIC MEDICAL JOURNAL

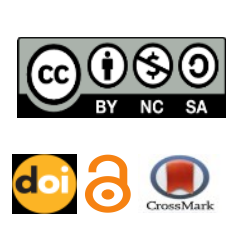

Review Article

ISSN: 23205091

Impact Factor: 5.344

\section{CONCEPT OF RAKTHA DHATU IN AYURVEDA}

\author{
Seeta M. Biradar ${ }^{1}$, Shruti Hiremath ${ }^{2}$, Renuka Tenhalli ${ }^{3}$, Sateesh Patil $^{4}$ \\ ${ }^{1}$ M.D.(Ayu), Ph.D (Scholar), Associate professor \& HOD, Dept. of Roganidana, \\ ${ }^{2}$ Assistant professor, Dept. of Kriyashareer \\ ${ }^{3}$ Professor \& HOD, Dept. of P.G Studies Samhita \& Siddhanta, \\ ${ }^{4}$ Associate professor \& HOD, Dept. of Swasthavritta, \\ BLDEA'S AVS Ayurveda Mahavidyalaya, Vijayapur, Karnataka, India
}

Corresponding Author: drseetabijapur@gmail.com

\section{https://doi.org/10.46607/iamj3208102020}

(Published online: October 2020)

Open Access

(C) International Ayurvedic Medical Journal, India 2020

Article Received:06/09/2020 - Peer Reviewed:28/09/2020 - Accepted for Publication:03/10/2020

\section{Check for updates}

\begin{abstract}
Rakthadhatu (Blood) is one of the seven dhatus. Word Rakthais taken from Devanagari "Raj Ranjane" which determines red shading. The functions of Raktha dhatu are clarified in many different views as Kala, Matrujabhav Twacha, Avayava Utpatti in Garbhavastha, Formation of Srotas, its Panchabhautiktva, Upadhatu, Pramana, Gunas, Mala have been clarified. Acharya Sushruta says its extreme importance for the sustainability of life. Therefore, it is very important to do the protect the Raktadhatu. Acharya Sharangadhara states that Rakthadhatu is life of shareer. The shareerdoshasangraha, dehasambhavahetava, Trayodoshasamasataha, that shows that Vata, Pitta and Kapha are 3 doshas and raktha cannot be called as Dosha. As we known, Rakthadhatu is different from the blood according to modern and carrier of Agni /pitta that invigorates the body and mind. All Dhatus get digested by the Tejas of Pitta dosha. As Yakrut is responsible for Rakthautpatti. The liver plays important role in metabolism. Acharyas have opined about the genesis of Yakrut (liver) from Rakta Dhatu (blood tissue). Parallel opinion in conventional anatomy states that abundant quantity of blood is responsible for the formation of sinusoids of liver. Ayurveda covers Raktadhatu in much wider aspect. Ayurvedic texts reveal that Raktadhatu has much broader concept than blood. Hence in this article concept of Raktha in Ayurveda are highlighted.
\end{abstract}

Keywords: Raktadhatu, Blood, Raktautpatti, Dhatu, Pitta 


\section{INTRODUCTION}

Raktadhatu is an entity which is considered as one of the Saptadhatus, which is unanimously accepted by all Ayurveda Acharya's. The word Rakta is derived from Sanskrit word RajaRanjane which indicates red colour. Synonyms of Raktadhatu are Rudhiram, Shonitam, Lohitam whereas rakthaoutpatti is dealt asAapya rasa ${ }^{2}$ (water like Rasa), the Aapya rasa (water like Rasa) after getting red colour by the Tejas (heat fire like agency) present in the body (in the liver and spleen) remaining unvitiated and clear comes to be called as Rakta. When the Aapya rasa passes through the Yakrut and Pleeha and by the action of the Ranjaka Pitta the Aapya gets converted into Raktadhatu. Essence of food known as Aahara rasa is formed by the action of Jatharagni (gastric juicehydrochloric acid) in the Amasaya (stomach) and is partially digested product. It passes through the Grahani (duodenum) gets mixed with Acchapitta (bile and pancreatic juice) reaches the Pachyamanasaya (small intestine). There it undergoes further digestion by the action of Bhutagni (metabolic process). After these activities are completed the first tissue known as Rasa dhatu get formed. This is white thin liquid containing nutrient materials essential for the formation and growth of other Dhatus (tissues). This Rasadhatu travels all over the body constantly supplying nutritive materials (Dhatuposakamsa/Posakadhatu or Asthayidhatu) to other static tissue (Sthayi or Posyadhatus). The ancient view that Rasadhatu goes to the Yakrut and Pleeha obtains red colour there and become Raktadhatu can be explained to some extent. Some portion of chyme absorbed from the small intestine goes to liver and spleen and form there reaches the heart. A red pigment called haemoglobin is synthesized in these organs (especially the liver) and is instilled into each of the $\mathrm{RBC}(\mathrm{Red}$ Blood Corpuscles) which are in great number and so make the entire fluid deep red in colour. In the living body Teja brings this red colour to Rasa dhatu and when produced in healthy manner and in physiological quantity; it is fresh and called Rakta. The Rasa dhatu though Aapya (liquid possessing and action of water) after reaching Yakrut and Pleeha attains red colour due to the action of Ranjaka pitta. Charaka said that when Teja portion of Ahararasa and Pitta (Ranjaka pitta) with Ushma acts upon Rasa it acquires redness. This is finally Raktata. As per modern science Blood ${ }^{3}$ is connective tissue in fluid form. It is considered as fluid of life because it carries oxygen from lungs to all parts of body and carbon dioxide from all parts of body to lungs. It is also called fluid of health because it protects body against diseases. According to Ram SundarRao, the essence of Aahararasa after being subjected to Paaka by Ranjaka Pitta attains red colour and become Raktadhatu'. As per Sushruta ${ }^{4}$ vein providing Rakta to each smallest structure of the body is additionally a base of Raktavahasrotas. Yakrut and pleeha are locales of arrangements and vitiation of Raktadhatu.

Visratadravataraagahaspandanamlaghutaatathaa|Bh oomyadeenamgunaahyetedrushyantechaatrashonite II (Susruta) Panchabhoutikatva ${ }^{6}$ of rakthadhatu resembling blood, the following qualities of blood represents the presence of their respective Mahabhutas and thus establish the fact that blood is Panchabhoutika.

Visrata - fleshy odour - Prithvimahabhuta, Dravata fluidity - Jalamahabhuta, Raga - redness - Agni mahabhuta, Spandana - movement Vayumahabhuta, Laghuta- lightness - Aakash mahabhuta

Properties of Rakta

Madhuramlavanamkinchitoshnamsamhatam $\mid$ Padmend riyopahemaavishashalohitalohita $\|\left(\right.$ A.H.Su 27/1) ${ }^{7}$

Raktadhatu ${ }^{8}$ pure or wholesome status looks like heated gold which turns red after heating, like fire insect (Indragopa) red lotus or like Abrusprecatorius (gunja) these various shades depends upon individuals. Sushruta ${ }^{9}$ also described characteristics of pure Raktadhatu. Raktadhatu looks like insect (Indragopa) is of proper density and does not bear any other colour than meant of pure blood raktadhatu is neither very cool nor very warm. It is sweet, unctuous, and red in colour, heavy, smells typically. Reacts to items which affect the pitta. As per Bhanumati 
commentary of Sushruta Raktadhatu is made up of Teja and Jalamahabhoot. In Hemadri, commentary on Astanga Hrudaya he described Aashryaashriyatva, in which he explained pitta has ashraya of Raktadhatu. It means if Pitta dushti occurs, it affects the normal Raktadhatu and vice versa. According to Ayurveda, the Rasa Dhatu, which comes to Yakrut and Pleeha, get colo red by Ranjakagni. But, this is too difficult to correlate with modern science. In the term of modern science, it can be matched with haematopoiesis. Haematopoiesis is carried out by Yakrut only in intrauterine life. However, after birth, this is carried out by red bone marrow. In some pathological conditions, the liver may help informing blood cells with red bone marrow. Actually, the function of Yakrut is metabolism of fats, proteins, etc., or storage of certain vitamins, nutrients or glycogen and not colouring the chyle. On the whole, the term of Ranjakagni related to the liver is too difficult to match with any of the components present in the liver.

\section{Rakta and Pitta correlation}

The Rakthadhatu being made up of primarily of Agni, has similar qualities. It is Ushna, Laghu, Rooksha, Khara, Asthayi. These qualities are very similar to Pitta dosha which is made up of Tejas and Apa. Sharangadhara(prathamkhanda $)^{10}$ The status of Rakthadhatu plays an important role in determining the status of pitta dosha. In the formation of Dhatu, Pitta is the mala produced by the formation of
Rakthadhatu.Raktha has special relation to the Yaktrut. Yakrut is the site of region of Rakthavahasrotas, which is the channel through which unstable form of poshya Rasa dhatu must pass prior to the formation of Raktha. When Rakthadhatu is overheated, so too is poshya Rasa dhatu. As a result the Yakrut and Pleeha become overheated and possibly gets enlarged. This is what occurs during Hepatitis. Some Acharyas have different opinion regarding utpatti of Rasadidhatus. Some believe that in one day all the 7 dhatus are formed whereas some comment that they take 7 days and $8^{\text {th }}$ day Shukra is formed.

\section{Rakthavahasrotomoola}

Elaborate description of Rakthavahasrotas and Rakthapradosajavyadhis are found in both Laghutrayas and Brhatrayas.

\section{Brhatrayees}

Acharya Charka describes Rakthavahasrotas in Vimanasthana $5^{\text {th }}$ chapter and Shonitajarogas in Sutrasthana $24^{\text {th }} \quad$ chpt and Rakthapradosajaanyavyadhis in $28^{\text {th }}$ chapter $^{11}$

Acharya Susruta describes Rakthavahasrotas and its dusti in Shareersthana $9^{\text {th }}$ chapter.

Acharaya Vagbhata followed views of Charak, Susruta

Acharaya Sharangadhara was the first to mention Rakthajananatmajavikaras. He has also mentioned kamala under Panduroganidana chapter itself.

Table 1: Aetiology of RakthavahaSrotas

\begin{tabular}{|c|c|c|c|c|}
\hline Sl No & Etiological Factors & References & & \\
\hline & & Charak & Susruta & Vagbhata \\
\hline 1. 1 & Aharaja & + & - & + \\
\hline 3. & Atikshara & + & - & + \\
\hline 4. & Atiamla & + & - & + \\
\hline 7. & Atikulatha & + & - & + \\
\hline 8. & Drava snigdhaguruni cha atyaadana & + & + & - \\
\hline 9. & Pindalu,moolaka & + & - & - \\
\hline 10. & Jalajamamsasevana & + & - & - \\
\hline
\end{tabular}




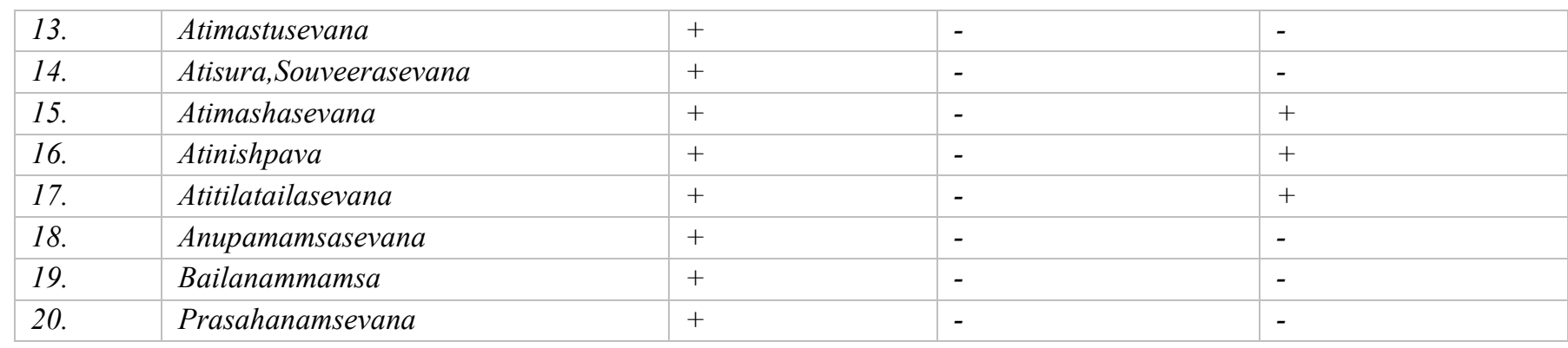

Table 2: Environmental Conditions

\begin{tabular}{|l|l|l|l|l}
\hline 1 & Sharathkala Swabhavataha & + & +
\end{tabular}

Table 3: Sedentary Habits

\begin{tabular}{|l|l|l|l|l}
\hline 1 & Bhutva diva prasvapnam & + & +
\end{tabular}

Table 4: Shreerika

\begin{tabular}{|l|l|l|l|l|}
\hline 1 & Shrama & + & + & - \\
\hline 2 & Abhigata & + & + & - \\
\hline
\end{tabular}

Table 5: Psychological

\begin{tabular}{l|l|l|l|l}
1 & Krodha,Chinta,Shoka,Bhaya & + & + & -
\end{tabular}

Materials \& Methods: All classics, articles, online materials are taken for the study.

\section{DISCUSSION}

Concept of Raktha Dhatu has got broad meaning compared to Blood in Modern. Raktha dhatu(blood) is an important entity in context to continue the Life. Because it performs important functions required for the body. As per Modern functions of Blood ${ }^{9}$ described as the Haemoglobin of RBC picks up oxygen in the Lungs and this Oxyhaemoglobin circulates $\&$ discharges oxygen into the Tissue, this is Respiratory Supply of Nutrients such as Glucose, Amino acids, \& Fatty acids absorbed from the GIT tract \& transported by the Blood to the liver, acts as Nutritive. Various waste products of the body are carried by the Blood \& ultimately removed from the body via Kidney, this is excretory function. Blood also helps in transport of various drugs, hormones etc to various tissue. It also helps in maintaining the body temperature, in process of Coagulation and also in detecting the foreign material by Antibodies. In Ayurveda Raktha dhatu is extremely important for the sustenance of life. Therefore, it is needed to protect this Dhatu by every possible measure. Rakthadhatu is also responsible for Dehadharan. Susruta also mentioned that Raktha dhatu is responsible for the nourishment of all dhatus \& plays vital role in the formation of organs. It considered as one of the Dashapranayatana, hence included in Dashapranayatana. In Susruta shareerasthana, it is explained that Raktha dhatu while circulating throughout the body gives Poshakansha to their respective dhatus \&helps in maintaining of strength of respective dhatus (dhatuparinama). Raktha dhatu is also responsible for Varnaprasadana. It also performs the function of sensation. In embryonic life, Raktha dhatu plays an important role in formation of liver, spleen, lungs, colon, kidney \& heart. A little wasting will not hamper function of Rakthadhatu immediately if Rakthadhatu is in excellence condition. Persons will have strength to fight the pathogenesis. Charak in Sutrasthana mentioned that Raktha is also responsible for formation of Oja \& Ayurvruddhi. Kshaya and Vrudhi of dhatus are also dependent on Raktadhatu. (Su.su14/21) (Shonitnimittaj). In Charak Sutrasthana 
$14^{\text {th }}$ chapter it is explained that if there is loss of Rakthadhatu in turn leads to diminished strength of other Dhatus, Agni \& Vatadosha gets aggravated. In Charak. Sutra $24^{\text {th }} / 11$. It is explained, if diseases are not cured by Sheeta, Ushna, Snigdha, Ruksha treatment then that diseases are called to be Raktajvyadhi. It indicates importance of Raktadhatu. Raktadhatu is one of seven Dushya in aetiology of Kustha and Visarpa. Charak Sutrastana $24^{\text {th }} / 24$ explained Vishudda Rakthapurusha Lakshanas as if persons organs are properly functioning, as such each of organs performing their respective functions as they mean. If digestion is proper and excretory functions are proper, it indicates proper functioning of Raktadhatu.

\section{CONCLUSION}

After viewing through the classics regarding Rakthadhatu, it maintains the life process. Modern sciences also described Blood as the fluid of life, as it carries Respiratory gases, nutrient materials required for the basic life process. Body cannot survive without Prana \& Rakthadhathu. Rakthasthana means either the site where Raktha is formed or stored. \& Pleeha have been recognised by Charak \& Susruta as Rakthasthana \& also moola of Rakthavahasrotas. Rakthadhatu circulates in the body \& supply nutrients to all dhatus\& responsible for existence, support\& maintenance of the body. The functions described in Ayurvedic texts of Raktadhatu are much more than that described in modern science. Raktadhatu gives us idea about vital fluid running through body, which connects Jatharagni to every other Dhatus of the body. These organs get nourishment through Raktadhatu and are responsible for nourishment and maintenance of good health.

\section{REFERENCES}

1. Susruta, Susruta Samhita (Nibandha Sangraha by Dalhan) Sutrasthan, Susruta Samhita, Edited by Jadavji Trikamji Acharya, Chaukhambha Subharti Prakashan, Varanasi, Sutrasthana chapter $14^{\text {th }}$,verse $6,8^{\text {th }}$ ed.2012.
2. Susruta, Susruta Samhita Kaviraj Ambikadatta Shastri, Chaukhambha Sanskrit Sansthan, Varanasi, Sutrasthana chapter $21^{\text {st }}$ page no $185,2^{\text {nd }}$ edition2002.

3. Health engine.com.au $>$ info $>$ blood-function-\&composition. (Health.engine.blog)

4. Dr M. Ramsundarrao, Shareer Kriyavijanan $2^{\text {nd }}$ edition, page no 268

5. Susruta, Susruta Samhita Kaviraj Ambikadatta Shastri, Chaukhambha Sanskrit Sansthan, Varanasi, Sutrasthana chapter $21^{\text {st }}$ page no 64, 2nd edition 2002.

6. Susruta, Susruta Samhita Kaviraj Ambikadatta Shastri, Chaukhambha Sanskrit Sansthan, Varanasi, Sutrasthana chapter $14^{\text {th }}$ verse 9 , page no 65 .

7. Paradar H.S.S, Astanga Hrudaya of Vagbhata, Sarvangasundaratta \& Ayurveda Rasayana of Hemadri, Varanasi, Sutrasthana $27^{\text {th }} \mathrm{chpt}$ 1sloka Chaukhambha Surbharati Prakashan, Sutrasthana $27^{\text {th }} \mathrm{chpt}$ 1sloka, Reprint Ed 2002.

8. Susruta, Susruta Samhita Kaviraj Ambikadatta Shastri, Chaukhambha Sanskrit Sansthan, Varanasi, Sutrasthan chapter14th, verse 22 page no 69, 2nd ed2002.

9. Sharangadhara Samhita, Durgadattashastri, Vaijyanatha Prasad Bukslehwar, Banarasacity, 1949page no 84

10. S. K. Choudhari, Concise Textbook of Physiology, $4^{\text {th }}$ edition page no 19.

11. Agnivesha, Charaksamhita, revised by Charak \& Dridhabala with commentary of Chakrapanidatta, edited by Jadavaji Trikamaji Acharya, Chaukhambha Sanskrit Sansthana, Varanasi, Sutrasthana, chapter $28^{\text {th }}$, verse 11, 12 page no $5985^{\text {th }}$ Edn, Reprint 2011.

\section{Source of Support: Nil Conflict of Interest: None Declared}

How to cite this URL: Seeta M. Biradar et al: Concept of Raktha Dhatu in Ayurveda. International Ayurvedic Medical Journal \{online\} 2020 \{cited October, 2020\} Available from: http://www.iamj.in/posts/images/upload/4778 4782.pdf 